INDEPENDENT JOURNAL OF MANAGEMENT \& PRODUCTION (IJM\&P)

\title{
QUALITY HACCP APPLIED TO FLIGHT CATERING INDUSTRY
}

David Souza Vaz Centro Paula Souza, FATEC Guarulhos, Brazil

E-mail: eniofr@uol.com.br

Isabella Caroline Novo Nobre Centro Paula Souza, FATEC Guarulhos, Brazil E-mail: isabella_novo@hotmail.com

Enio Fernandes Rodrigues Centro Paula Souza, FATEC Guarulhos Federal Institute of São Paulo - Suzano Campus, Brazil

E-mail: eniofr@uol.com.br

Luiz Teruo Kawamoto Junior Federal Institute of São Paulo - Suzano Campus, Brazil E-mail: luizteruo@hotmail.com

Submission: 31/03/2016 Accept: 31/03/2016

\section{ABSTRACT}

The quality industry try to standardize the production procedures, actions and controls work in a uniform manner so as not to cause errors in operation and customer dissatisfaction, bringing the final product according to the requested specifications. With the duty to commitment with the consumer, many companies try to answer the questions of the quality applying techniques so that their processes are so tiny they are done in the most correct and accurate as possible. Since 2008 noted a growing importance as the HACCP due the major problems occurred in the handling of food, such as food poisoning, foreign objects and sanitary quality, which are the largest and most serious problems resulting from the production process, thus generating a new culture and the care of the food. 
Considering the importance of the issue of the impending population growth that carry air travel as well as international agreements between countries and continents, it has being demonstrated the effectiveness of the system demonstrating in practice how they work their analysis of points of danger and an investigation into the operational process within the context of the food industry.

Keywords: Catering. HACCP. Safety. Operating Process.

\section{INTRODUCTION}

The incessant seek for improvements, applications of new models aiming to improve the health and quality of food; it is present from the specific quality control systems to feeding in the aero system. A base, or even a network of airline catering industries, production services and distribution of food on board, effective and appropriate whose main scope and quality inspection in their food, ensuring the consumers integrity and health. In a specialized industry of production of meals, tools are inserted to ensure safety in its production chain and the pursuit of continuous improvement on processes.

The air transportation has become the choice among international trips and business, as well linked to this growing change, on board feeding service has become one of the key factors of providing quality and usefulness within the catering industry. Its main goal pervades not only on taste satisfaction, but also primordially in guarantee the food safety.

With the application startup in its first instance, NASA (National Aeronautics and Space Administration) as a tool called HACCP (Hazard Analysis and Critical Control Points) has brought some significant and positive results in its first use; it has been introduced afterwards in other businesses/industries.

Thus, the HACCP system can be presented as a model or technique that minimizes the possible failures and allows a business relationship between the main active professionals of the logistics chain, benefiting the security needed to the feeding.

This study evaluates how the HACCP system works, its changes in organizational processes within the feeding industry in order to analyze their behavioral impacts in everyday situations. 


\section{BACKGROUND}

According to the company studied, the amount of service of a large catering air is high, reaching up to around 200 flights/day, and usually the flight is composed by Captain (Pilot) and Copilot, expressing as a whole about 400 meals, only for the technical air staff. If we calculate the amount of passenger in the standard class on average 150 passengers per flight, the result will about 30,000 meals per day, plus 10,000 for business and first class, expressing as a whole about 41,000 meals/day. It is a large amount of production of ready-made food, even for a large company.

The revenue of a catering to an international company (services for long journeys, more than 3 hours) average costs $R \$ 13,000.00 /$ flight, which included the airport tax, representing $8 \%$ of the total invoice. Since national companies, about 100 flights/day, the annual revenue reaches $R \$ 60,000,000.00$, and the values can be predicted and already agreed in the contract.

\section{OBJECTIVE}

The focus is to demonstrate the impact of technical implementation of HACCP in an organization of supplying food to companies linked to air passengers.

Which the specific objectives refer to:

- Provide reliable food;

- To minimize the possible occurrences in the supply;

- Ensuring quality during the process in the production chain;

- Identification the origin of inefficiency in the process;

- Improvement in food security system and operational performance.

\section{PROBLEMATIC}

Microbiological changes in food composition and instances of foreign objects in meals are occurring and can be caused by an inefficient supply chain that begins at the reception of the raw material, through the handling, transport and distribution, compromising the security of meals supply on board of air transport, bringing negative impacts. 
INDEPENDENT JOURNAL OF MANAGEMENT \& PRODUCTION (IJM\&P)

http://www.ijmp.jor.br

v. 7, n. 5, Special Edition IFLOG 2015

ISSN: 2236-269X

DOI: 10.14807/ijmp.v7i5.460

\section{HYPOTHESIS}

Food quality commitment provided by airlines to passengers can significantly affect satisfaction and performance of the organization. Thus, using the HACCP technique in the process of handling and preparing food can create behavioral changes in the operational processes, as reduce failures and minimize the risks linked to food security, improving the business relationship in front of the partnership between the companies and the food industry.

\section{METHODOLOGY}

The study aims to survey the theoretical framework which quality and technical matters of food handling have been addressed, where as proof of its implementation was done a monitoring of the process for preparing two types of meals of the same food group (according to the tool) which will be described in the study.

Visits and observations were made where there is manufacturing process, identifying 5 Critical Control Points from the specific supply chain to air catering under studies, thus presenting each step used in the industry collecting such information related to HACCP and its CCP tool technique.

For data analysis it is listed information related to the temperature of food - for each food group is set a minimum or maximum temperature for non-microbiological development that may result in health problems if eaten - and their ways of packaging and handling, thus ensuring the meal for distribution in accordance with the safety standards.

\section{THEORETICAL BASIS}

\subsection{Food Safety In The Food Industry}

Many of the tools aimed at food security have been adapted to constant technological advances and the needs of products that require the safety health, as well as contemplation in trade relations and especially respect for the consumer. (PERETTI; ARAÚJJO, 2010).

In the catering business is noteworthy the growing concern in relation to the duty to provide safe products to its customers, respect for the quality and commitment of everyone involved in the process are extremely important for achieving the goal, and cherish the corporate image. 
DOI: $10.14807 /$ ijmp.v7i5.460

To Capiotto and Lourenzani (2010) the Food Safety Management System is concentrated in the administrative activities of an organization guaranteeing consumers safe products.

For this reason the quality must be present in all operational steps as it has become a way for businesses to possess competitive advantage over their competitors covering even the international market.

Among the most respected models and indicated the deployment and use of safety management in food businesses in order to feed reliability to be offered to consumers, are the uses of the qualities of BPF (Boas Práticas de Fabricação) determined by the Ministry of Health and agriculture, technical HACCP (Hazard Analysis and Critical Control Points) to ISO 22000 and PPHO (Procedimentos Padrão de Higiene Operacional). (GOBIS; CAMPANATTI, 2012).

The HACCP associated with BPF and PPHO has been revealed as a basic model for the food industry as it ensures product safety, cost reduction since no rework generating increased profitability of processes and profitability. (TOBIAS; PONSANO; PINTO, 2014).

In recent decades the security of quality has undergone major changes, the measures passed corrective to preventive. Since the management of food security, the state intervenes to respect the consumer regarding Food safety rules determining how a product recall and appropriate measures against those responsible.

The HACCP model applied to catering to study follows the procedures and criteria established in accordance with its superordinate organ, meeting all the requirements, mainly from ANVISA (Agência Nacional de Vigilância Sanitária).

\subsection{Air Transport}

According to Bielschowsky and Custodio (2011) the growing demand of air transportation was mainly by economic diversity and growth that Brazil passed between the 1920s to the early 1960s, was in this period that the shuttle was marked by a high rise.

According to researches by the OMT (Organização Mundial do Turismo) in the Tourism Towards 2030, the number of international tourists will grow $3.3 \%$ annually between 2010 and 2030 surpassing 1,400 million in 2020 and 1,800 million in 2030 . 
(OMT, 2013). In Brazil air travel is the primary means of locomotion tourist demands and is the most significant element for growth and consolidation. The constant changes and needs in the modal occur in the course of globalization, and have been implemented since the beginning services for the convenience of passengers.

In-flight service was getting innovations over time, thank to technologies that then arose. In Brazil, starting from nonexistent and larger companies such as VARIG, VASP and TransBrasil introduced high-standard services since at that time only highincome people were using such transport. (BRITISH AIRWAYS, 2015).

\subsection{Development Of Air Catering}

The first airline to serve hot food on board was Lufthansa in April 29, 1928, for SXF (Berlin) to CDG (Paris). The B-31 aircraft accommodated 15 passengers and had a layout structured for providing the service. The first air independent kitchen was developed in 1946 by the International Dobbs paying service Delta Airlaines in Atlanta. The BELA in 1967 organized his own catering at Heathrow, was from that point that other companies began to emerge in the market as the CaterAir International, LSG SkyChefs, Ogden Aviation Services, Chelsea Catering, CA One Services, Gate Gourmet and so on. (Jones, 2004).

From the twentieth century on, as all other branches of other industries had its rise, the catering was no different. Starting its evidences with the Zeppelin airship, to serve champagne and sandwiches, and being structured with the first hot meal with the great German Lufthansa, creating your own kitchen (LSG Sky Chefs) post Dobbs International.

\subsection{Catering Operations}

"In aviation, Air Catering companies are preparing meals for airlines. They are responsible for adapting the production of industrial kitchen to the world of aviation peculiarities ". (STETTINER et al. 2015, p. 478).

Due to the complexity of aviation, food industry had to adapt and create a whole system in order to be able to meet the need that air world demands, due to this complexity and hence uniqueness of each airline, each catering establishes its flow from operations internally waking will be processed as requests coming from airlines and their distribution to the clothing of the dishes. 
DOI: 10.14807/ijmp.v7i5.460

The internal organizational hierarchy plays a key role, since the integration of all its resources benefits the reach of global competitiveness, as the internal guidelines of a company. (LISBON et al, 2013)

To make more efficient processes and more likely to be administered, each operating sector has its manager, as designed in the hierarchical pyramid:

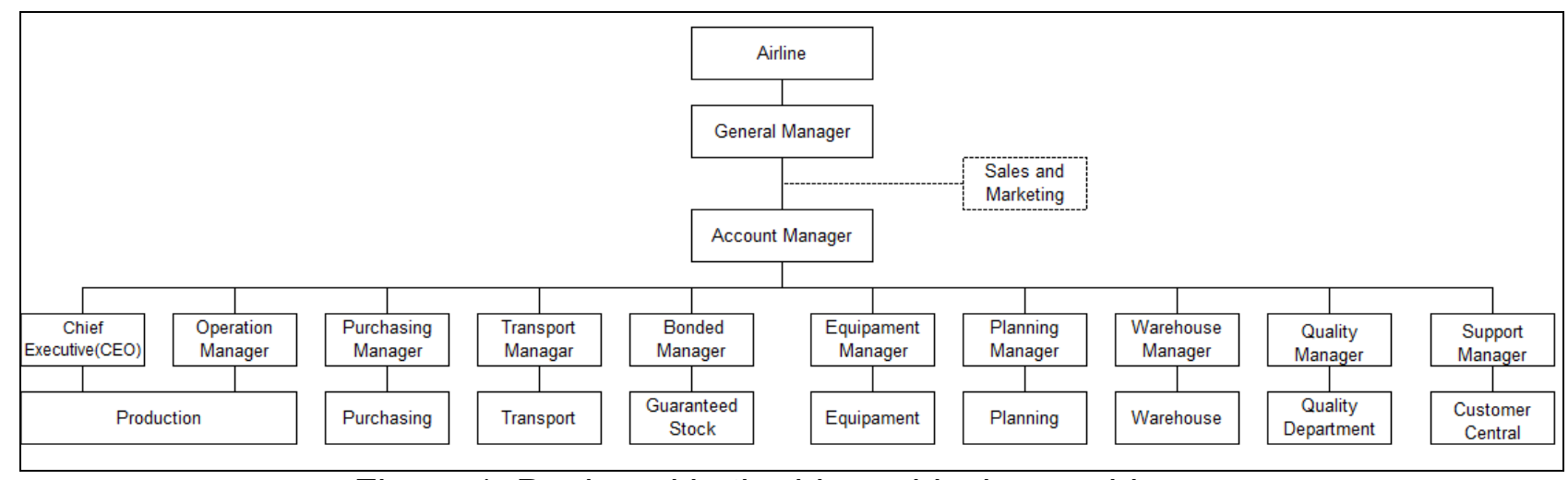

Figure 1: Designed in the hierarchical pyramid

The teams involved in catering are characterized by well-defined and objective hierarchies. It is extremely important the integration of the teams in all activities and the definition of those responsible for each part of the process. The possible indication of a problem of focus decision-making should be stipulated to control resumed.

\subsection{Quality HACCP}

Several companies are achieving all requirements in order to respect the quality and commitment of everyone involved in such a specific process in the most correct and rigorous way, therefore, several quality tools have been developed with the aim of commitment with the consumer.

According to Junior et al. (2010) a quality management application and its implementation in organizations which develop projects has been perceived as epicenter of conflicts, however, the systems view of quality with the tools allows the improvement of conditions, minimizing risks and in favor of monitoring.

Using of tools to quality management is essential, so, surveillance, inspection, guidelines and standards to be followed by producer organizations and food service providers the population is given as a mandatory factor. 
DOI: $10.14807 /$ ijmp.v7i5.460

The HACCP (Hazard Analysis and Critical Control Points) is a system aimed at preventing a potential contamination, rather than just analyzing the final product (FAO, 2011). The reasons of food contamination are mainly the lack of proper procedures in steps coming from raw material to final product.

We can mention the example of the incorrect handling of food and incorrect temperatures at which each food requires, since the micro-organisms are becoming increasingly resistant addition, the lack of resources and training that many companies still have great need for excellence their service.

The tool is the most appropriate to the international quality assurance control cell which OMS (Organização Mundial de Saúde), Codex Alimentarius, the FAO (Food and Agriculture Organization) and the European Community and the United States require as template and guidance on production. (INMETRO, 2009). In Brazil, in addition to these organs, it is also required by Federal Decree 1428/93 the Ministry of Health. (BRASIL, 1993).

The Codex has the functionality to protect the health of the population and ensure both national as international practices. According to Ortega and Borges (2012) with regard to food hygiene, the use of HACCP is introduced through the texts of the General Principles of Food Hygiene of Codex in ensuring safety. The Codex defines the development of practices, manufacturing, transportation and storage of food groups or certain foods.

Since the Boas Práticas de Fabricação (BPF) consists of a program of standards and prerequisites aimed at certifying the quality and safety of food products, for the implementation of HACCP in industries (TOMICH et al. 2005). Since the lack of this practice directly influences the control of Critical Control Points thus increasing the identification of trouble spots in the process.

According to Silva (2013) in airline catering risks in food are more frequent than in the conventional food industry, especially the room temperature factor unstable, it comes to long trips in which problems may have originated or raw material, or cold chain, hot chain, cross contamination, handling or even inadequate methods of hygiene both in equipment such as those involved in the process.

The danger consists of biological, chemical and physical agents that cause harmful effects to the health of consumers (BRASIL, 1999). 
DOI: $10.14807 /$ ijmp.v7i5.460

The identification and analysis of risks are characterized by different stages of management, which involves identifying and spare characterization of scientific knowledge. (ANVISA, 2013).

The HACCP system uses standardized seven principles that are controlled and monitored every step of the process. According to Paula and Ravagnani (2011) seven principles are:

i. Analyze the possible risks and their countermeasures: identification of potential dangers from the initial process to the final determining their probability of occurrence and prevention measures;

ii. Highlight the critical control points: operational steps to minimize or eliminate the danger;

iii. Establish critical limits: principle that establishes that all CCPs are under control;

iv. Establish monitoring the CCP: analysis, tests and observations;

v. Establish corrective actions, since the CCP: it does not comply with the standards. The actions established in this step should ensure control of return;

vi. Establish oversight, checking the effectiveness of processes: audit and analysis in the validation of correct procedures of the HACCP system are made at this stage;

vii. Establish documentation for all procedures: registration of all stages and monitoring.

The Critical Control Points is a stage that there is a risk, and then applied preventive measures to control, eliminating, preventing or reducing that fault. In airline catering in the study of food preparation processes are done in 5 stages of Critical Points, which a according to each food group should not be performed according to established norms. The model used by the company is presented in the following chart: 
INDEPENDENT JOURNAL OF MANAGEMENT \& PRODUCTION (IJM\&P)

http://www.ijmp.jor.br

v. 7, n. 5, Special Edition IFLOG 2015

ISSN: 2236-269X

DOI: 10.14807/ijmp.v7i5.460

Table 1: Description of the 5 Steps Used the CCP - 2015

\begin{tabular}{|c|c|c|c|c|c|c|}
\hline & & \multirow{2}{*}{\multicolumn{5}{|c|}{ Description }} \\
\hline & & & & & & \\
\hline & & What? & Where? & When? & How? & Why? \\
\hline CCP01 & Reception & $\begin{array}{l}\text { Product temperature conditions: } \\
\text { Packaging, Appearance, Label, } \\
\text { Community Garden, manufacture and } \\
\text { validity; Storage (truck) } \\
\end{array}$ & $\begin{array}{l}\text { Entry in the } \\
\text { Warehouse }\end{array}$ & $\begin{array}{l}\text { Time of } \\
\text { delivery }\end{array}$ & Verify & $\begin{array}{c}\text { Ensure raw } \\
\text { material }\end{array}$ \\
\hline $\mathrm{CCP} 02$ & Storage & $\begin{array}{c}\text { Conditions of Temperature and } \\
\text { Environment }\end{array}$ & Warehouse & After Receving & Verify & Ensure packaging \\
\hline CCP03 & Cooking & $\begin{array}{l}\text { High temperature of food in its } \\
\text { geometrical center }\end{array}$ & $\begin{array}{l}\text { Departiment } \\
\text { cooking }\end{array}$ & After Cooking & Verify & $\begin{array}{c}\text { Ensure not } \\
\text { proliferation of } \\
\text { bacteria }\end{array}$ \\
\hline CCP04 & Cooling & $\begin{array}{l}\text { Low temperature of food in its } \\
\text { geometrical center }\end{array}$ & Blast Chiller & $\begin{array}{c}\text { After } \\
\text { processing by } \\
\text { cooking } \\
\end{array}$ & Verify & $\begin{array}{c}\text { Ensure not } \\
\text { proliferation of } \\
\text { bacteria }\end{array}$ \\
\hline CCP05 & Building & $\begin{array}{c}\text { Temperature and Food Handling } \\
\text { Time }\end{array}$ & $\begin{array}{l}\text { Departiment of } \\
\text { dish cooking }\end{array}$ & $\begin{array}{l}\text { After Cooling } \\
\text { the Blast Chiller }\end{array}$ & $\begin{array}{l}\text { Verify and } \\
\text { control time }\end{array}$ & $\begin{array}{l}\text { Ensure not } \\
\text { proliferation of } \\
\text { bacteria }\end{array}$ \\
\hline
\end{tabular}

\section{STUDY OF CASE}

The company under investigation is the leading global airline catering segment and its main span of service on board, it is part of a European group between branches and head office which has more than 150 companies that are increasingly on the rise, and up to now serves in 52 countries across Asia, Africa, Europe, North and South America. In 2014 were produced more than 600 million meals to the global aviation, from freighters, through executive jets, which the domestic flights is the most part of the revenue in the industry.

Its growth accrues from the high rates of flights on a global scale, as aviation is reaching large peaks of air trips since the 90 s, aviation-related company has grown considerably in proportion to air transport.

Its focus is on the quality of operational processes as a key point in the excellence of its services. In relation to the process of all preparation of food to be consumed, the tool used in the production chain is the HACCP, being used internationally by catering companies and also by other companies in the food industry which are adopting the technique as an improvement model in their productive chain. 
DOI: $10.14807 /$ ijmp.v7i5.460

The application shown in the study consists of the steps of the Critical Control Points that at each stage and any minimal occurrence and the probability of an eminent risk, preventive measures will be implemented by eliminating or reducing this danger. It can be in the physical form as hair, glass shards, nail-chips etc. or chemical form, for example, cleaning products and poisons pests among others and finally biological risks consisting be the most dangerous.

Visits and observations were made in the manufacturing process sites, identifying the analysis of the 5 Critical Control Points in supply chain, specific to air catering under study, from receipt of raw materials to the food handling.

\subsection{CCP $01-$ Reception}

It is the first critical point that should be checked on receipt of the goods. It is at this stage that there is a verification on the conditions of the food being delivered, it should be considered some important points, such as:

- Food temperature;

- Packaging Verification: clean and inviolate;

- Product appearance;

- Labels should contain the name of the product;

- Lot, manufacture and validity;

- Truck cleaning conditions ensuring that there are no insects or pests;

- Correct transport in cleaned boxes and pallets.

The responsible person for delivering of the goods must follow the statutory guidance system as wearing cap, uniform and being shaven. And the responsible for the receipt of goods has full responsibility to ascertain such measures and write down on a sheet in case the CCP 01 documentation.

If the product does not comply, the product should be discarded and be made to return to the supplier and the it must be notified of the problem. It is also important to complete the claims form the supplier that must be signed by a person responsible to the Purchasing Department. They must withdraw two copies, because one will get the delivery, the other with the receiving dock and original to the Department of Quality 


\subsection{CCP 02 - Temperature Chambers And Enviroment}

This step is important to note that bacteria do not multiply at quite low temperatures, so to ensure the safety and preservation of food is required to be made constant monitoring of the chambers and environment temperature. The ambient temperature should be at $15^{\circ} \mathrm{C}$ and the temperature of cold room $5^{\circ} \mathrm{C}$ and Freezers $18^{\circ} \mathrm{C}$. Since the temperature of the defrosting chambers should not exceed the $8^{\circ} \mathrm{C}$. If it is not in the standards it should be operated to maintain promptly.

\subsection{CCP 03 - Heat Treatment Of Food}

Cooking temperature control procedure of food is an important point, because the most part of bacteria die at high temperatures. Foods that are cooked should reach the minimum temperature in its geometrical center, to check that it is used a cookery thermometer.

The professional responsible for cooking must register the temperature of all foods with no exception. If the food does not reach the required temperature, as a corrective action the food must be reheated.

According to each food group of animal origin such as meat, fish, poultry and eggs should be achieved the required minimum temperature:

- Group A (temperature + 74C - Instantaneous) - Goulash, Bobó, Stroganoff, Burger, Poultry, Bovine Meat, Fish and Stuffed Pasta;

- Group B (temperature $+70^{\circ} \mathrm{C}$ - Instantaneous) - Scrambled Eggs and omelets, shrimp, shellfish (Minced);

- Group C (temperature $+65^{\circ} \mathrm{C}$ - Instantaneous) - Beef and lamb meat;

- Group D (temperature + 66C - For 1 Minute) - Whole Beef Roast (Eyeround and roast beef);

- Group E (temperature $+63^{\circ} \mathrm{C}$ - For 15 seconds) - Tournedor Meats (Sealed);

- Group F (temperature $+63^{\circ} \mathrm{C}$ - For 15 seconds) - Sliced Bacon, Loin / BuiltPlated and Tenderloin to Plati Plated.

\subsection{CCP 04 - Cooling Food}

Part of the process, which is done the control of time and cooling temperature of food after they have gone through cooking. As mentioned bacteria are very 
DOI: $10.14807 /$ ijmp.v7i5.460

sensitive to environment and temperature. Most die at very high temperatures and it is difficult to them to multiply in such cold areas.

So there is in the catering what is called the Danger Zone, which are temperatures from $10^{\circ} \mathrm{C}$ to $60^{\circ} \mathrm{C}$, and the multiplication of bacteria occurs. The cooling process minimizes the risk of contamination, because the passage through Danger zone is reduced to a shortest possible time.

At the cooking process, the heating from outside to inside is made, as the cooling is also carried out in the same way. It is very important to measure the temperature of food in its geometrical center.

The professional responsible for firing blast chiller sector, should make records in the CCP Form 04 daily to all kinds of food passing through the cooking process. Remembering that the professional must be careful to potentially dangerous products, such as meats, omelets and chicken.

No food can leave the blast chiller without having passed through the cooling process. Since it is dangerous to use warm food, or warm in the assembly of the dishes, as can occur multiplication of bacteria, contaminating them.

\subsection{CCP 05 - Temperature And Food Handling Time}

This is the last step of the whole process and refers to the temperature and time of food handling. The ambient temperature in a catering does not exceed $15^{\circ} \mathrm{C}$ and the time of preparation for each plate may not be exceed the specified time to each dish.

Following the controls of all the CCP will be demonstrated according to the survey in the business catering which were applied in the stages of production in chicken and meat options.

The service for chicken was made up of: the Chicken Parmesan, Tomato Sauce, Mix Vegetable and Sauté Potato; and the service for meat was made up of: Goulash Rump Steaks and Carrots, Mashed Potatoes with Garlic, Black Olive and Carrot Stick. The total volume in the same services was 75 chicken options and 75 meat options. 
INDEPENDENT JOURNAL OF MANAGEMENT \& PRODUCTION (IJM\&P)

http://www.ijmp.jor.br

v. 7, n. 5, Special Edition IFLOG 2015

ISSN: 2236-269X

DOI: 10.14807/ijmp.v7i5.460

\subsection{Trancking CCP (CRITICAL CONTROL POINT)}

Table 2: Tracking of Process: Poultry and Beef

\begin{tabular}{|c|c|c|c|c|}
\hline & & \\
\hline & & Conducted Monitoring & $\begin{array}{c}\text { Standard } \\
\text { application }\end{array}$ & Evaluation \\
\hline CCP01 & Reception & $\begin{array}{l}\text { Chicken fillet } 1^{\circ} \mathrm{C} \\
\text { Rump } 2^{\circ} \mathrm{C}\end{array}$ & $8^{\circ} \mathrm{C}$ (Cold) & Assured \\
\hline $\mathrm{CCP} 02$ & Storage & $\begin{array}{c}\text { Warehouse Chamber } 2^{\circ} \mathrm{C} \\
\text { Chicken Butchery Chamber } 4^{\circ} \mathrm{C} \\
\text { Meat Butchery Chamber } 4^{\circ} \mathrm{C} \\
\text { Cooking Chamber } 5^{\circ} \mathrm{C} \\
\text { Warm Cell Chamber } 5^{\circ} \mathrm{C} \\
\text { Holding Box Chamber } 4^{\circ} \mathrm{C}\end{array}$ & $5^{\circ} \mathrm{C}$ (Cold) & Assured \\
\hline $\mathrm{CCP} 03$ & Cooking & $\begin{array}{c}\text { Chiken Parmeggiana } 78^{\circ} \mathrm{C} \\
\text { Goulash Rump } 86^{\circ} \mathrm{C}\end{array}$ & $\begin{array}{c}74^{\circ} \mathrm{C} \text { - Poultry and } \\
\text { meat with sauce }\end{array}$ & Assured \\
\hline CCP04 & Cooling & $\begin{array}{l}\text { Chicken In } 1 \text { Hour And } 55 \\
\text { Minutes From } 66^{\circ} \mathrm{C} \text { To } 6,1^{\circ} \mathrm{C} \\
\text { Rump Steak Goulash From } \\
67,1^{\circ} \mathrm{C} \text { to } 5,1 \mathrm{C}^{\circ} \text { In } 3 \text { Hours }\end{array}$ & $\begin{array}{l}\text { In } 4 \text { Hours From } \\
60^{\circ} \mathrm{C} \text { to } 10^{\circ} \mathrm{C}\end{array}$ & Assured \\
\hline CCP05 & Building & $\begin{array}{c}\text { Option Chicken: } \\
\text { Chiken parmeggiana: in } 30 \\
\text { minutes of exposure from } 8,4^{\circ} \mathrm{C} \\
\text { to } 9,8^{\circ} \mathrm{C} \\
\text { Option Meat: } \\
\text { Goulash: in } 30 \text { minutes of } \\
\text { exposure from } 7,4^{\circ} \mathrm{C} \text { to } 9,4^{\circ} \mathrm{C}\end{array}$ & $\begin{array}{l}\text { In } 45 \text { minutes of } \\
\text { exposure up to } \\
12^{\circ} \mathrm{C}\end{array}$ & Assured \\
\hline
\end{tabular}

According to all tracking, steps of that food reached the required food safety criteria, with no great risks to the health of those who will consume them. It is important to mention that the incubation time of the bacteria can be between 6 and 48 hours after ingestion of contaminated food and differs according to the characteristic of the microorganism. Therefore in cases of suspected food poisoning it is essential to be realized the "recall" of the food consumed in the last 48 hours (previously to the symptoms), further on the description of the symptoms. It is also important to mention that appropriately skilled teams with common sense decision to practice any taken precautions to minimize or oppose potential risks to health should review the records daily.

\section{CONCLUSION}

According to the HACCP tool and application of its 5 Critical Control Point presented in the study was possible the analysis of an improvement in the adequacy of the food handling, reaching the specifications transmitting reliability which the 
DOI: 10.14807/ijmp.v7i5.460

scenery guarantees the insured product, avoiding disagreements versus specifications.

The principles highlighted ensure the food conditions from reception, which are checked temperatures, packing labels, dates of manufacture and expiry, and especially the truck cleaning process, through storage in the catering warehouse, cooking, cooling the blast chiller and assemblage controlling the temperature and way of handling, making it possible to identify the chemical, physical and biological risks. In fact, it was not observed in this case as in all steps verified the product has been identified in specifications, required norms and standards.

When preparing teams according to the specifications and requirements of HACCP methodology, conditions to the improvement of security and operation where it takes place, since everyone can understand and have an overview of all integrated processes.

Thus, it was possible to notice that in addition to bringing the benefits specified before the conduct HACCP, principles also reflect on the safety for the passengers' integrity. Leading the good relationship between the airline and its customer, consequently enhancing the business relationship front of the partner company and catering, ensuring effective gains and mainly upgrading in the quality of their operational processes, providing comfort and integrity to the airline while paying their board service.

\section{REFERENCES}

ANVISA. Guia Para Comprovação da Segurança de Alimentos e Ingredientes. Gerência de Produtos Especiais Gerência Geral de Alimentos. Brazilian. 2013.

BIELSCHOWSKY, P; CUSTÓDIO, M. C. A Evolução Do Setor De Transporte Aéreo Brasileiro. Electronic Journal New Focus. V. 13, n. 13, p. 72 - 93, 2011.

BRASIL. Agência Nacional de Vigilância Sanitária. Republica Resolução RDC $n^{\circ} 17$, de 19 de Novembro de 1999, Published DOU of 11/22/1999. Resolution Republic No. 362 of July 29, 1999.

BRASIL. Agência Nacional de Vigilância Sanitária - Portaria n 1.428/MS, de 26 de Novembro de 1993, Published DOU of 02/12/1993. To approve the Technical Regulations for the Food Sanitation Inspection. 1993. 
BRITISH AIRWAYS (2015) History and Heritage. Available in: <http://www.britishairways.com/en-gb/information/about-ba/history-and-heritage>. Accessed: September 8.

CAPIOTTO G. M.; LOURENZANL W. L. (2010) Sistema de Gestão de Qualidade na Indústria de Alimentos: Caracterização da norma ISO 22000: 2006. Brazilian Society of Economics, Business and Rural Sociology. Campo Grande.

FAO - FOOD AND AGRICULTURE ORGANIZATION OF THE UNITED NATIONS (2011) Codex Alimentarius. Food Hygiene Basic Texts. $20^{\circ}$ Edition. FAO and WHO Rome.

FIGUEIREDO, V.; NETO, P. (2001) Implantação do HACCP na Indústria de Alimentos. Gestão \& Produção, São Carlos, v. 8, n. 1, p.100-111, April.

GOBIS, M. A.; CAMPANATTI, R. (2012) Os Benefícios da Aplicação de Ferramentas de Gestão de Qualidade Dentro das Indústrias do Setor Alimentício. Magazine Horus, Ourinhos, v. 6 n. 1, p. 26-39 January / March.

INMETRO - INSTITUTO NACIONAL DE METROLOGIA, QUALIDADE E TECNOLOGIA (2009) Technical Assistance to the "Support Project for the international integration of Brazilian SMEs" PAIIPME. Study of the Food Chain: Access Mechanisms to the US market. Brasilia. Idaim Consulting.

JONES, Peter (2004) Flight Catering. $2^{\circ}$ Edition. Oxford. Elsevier Butterworth Heinemann Ltd.

JUNIOR M. I. et al. (2010) Gestão da Qualidade. 10th Edition. Rio de Janeiro. Editora FGV.

LISBOA, João et al. (2013) Introdução à Gestão de Organizações. 3rd Edition. Sao Paulo, Editora Economic Life.

PEARSON A.; DUTSON T. R. (1995) HACCP in Meat, Poultry and Fish Processing. $1^{\circ}$ Edition. Chapman \& Hall. Springer - Science Business Media B, v. 10.

OMT - ORGANIZAÇÃO MUNDIAL DO TURISMO. (2013) Panorama do Turismo no Mundo $2013 \quad$.Available in: <http://www.dadosefatos.turismo.gov.br/export/sites/default/dadosefatos/estatisticas indicadores/downloads_estatisticas/Estatistica_e_indicadores_Turismo_no_mundo_ 2013.pdf> Accessed on: Sept. 7.

ORTEGA, A. C.; BORGES M.S. (2012) Codex Alimentarius: A Segurança Alimentar Sob A Ótica Da Qualidade. Food Security and Nutrition, v. 19, n. 1 p. 71-81, 2012.

PAULA, S. L.; RAVAGNANI, S. M. A. (2011) Sistema ACCPP (Análise de Perigos e Pontos Críticos de Controle) de Acordo Com a NBR ISSO 22000. Technology magazine. Maringá, v. 20, p. 97-104.

PERETTI, A. P. R.; ARAÚJO M. W. C. (2010) Abrangência do Requisito Segurança em Certificados de Qualidade da Cadeia Produtiva de Alimentos no Brasil. Gest. Prod. São Carlos, v. 17, n. 1, p. 35-49, February.

SILVA, Eneo. (2013) Manual de Controle Higiênico - Sanitário em Serviços de Alimentação. 6. Edition St. Paul:. Varela. 
STETTINER, C. et al. (2015) Gestão de Estoque da Alimentação Hala no Serviço de Bordo de Aeronaves. Business and Management Review. Special Issue, V. 04, n. 08, p 477-483, March.

TOBIAS, W.; PONSANO, G. H. E.; PINTO F. M. (2014) Elaboração E Implantação Do Sistema De Análise De Perigos E Pontos Críticos De Controle No Processamento De Leite Pasteurizado Tipo A. Rural Science, Santa Maria, v. 44, n. 9, p. 1608-1614, September.

TOMICH, R. et al. (2005) Metodologia para Avaliação das Boas Práticas de Fabricação em Indústrias de Produção de Queijo. Ciênc. Tecnol. aliment; Campinas, v. 25, n. 01, p. 115-120, January / March. 